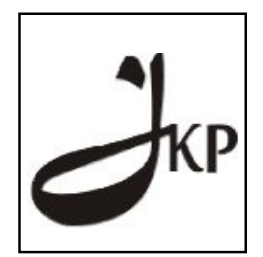

Jurnal Konseling dan Pendidikan

ISSN Cetak: 2337-6740 - ISSN Online: 2337-6880

http://jurnal.konselingindonesia.com

Volume 1 Nomor 3, November 2013, HIm 28-35

Info Artikel:

Diterima 01/11/2013

Direvisi 12/112013

Dipublikasikan 29/11/2013

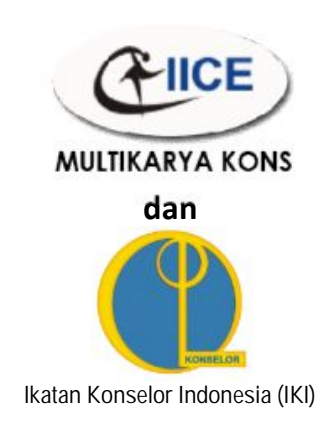

\title{
Kinerja Dosen Penasehat Akademik dan Hubungannya dengan Masalah Akademik Mahasiswa dalam Perkuliahan Guru
}

Nefri Anra Saputra, A. Muri Yusuf \& Syahniar

Universitas Negeri Padang

Abstract

Penelitian ini berawal dari rendahnya kinerja dosen penasehat akademik yang diketahui berdasarkan wawancara yang dilakukan dengan mahasiswa jurusan TV dan FILM ISI Padangpanjang. Kinerja dosen penasehat akademik adalah sesuatu yang telah dicapai oleh dosen penasehat akademik yang diukur melalui persepsi mahasiswa dalam melaksanakan tugas dan tanggung jawab yang diberikan kepadanya berdasarkan kompetensi yang dimilikinya. Jenis penelitian adalah korelasional deskriptif. Dalam penelitian ini terdapat populasi sebesar 135, teknik pengambilan sampel teknik Simple Random Sampling dan diperoleh jumlah sampel 100. Pengumpulan data dengan skala likert, dan analisis data dengan analisis deskriptif korelasional. Hasil penelitian menunjukkan bahwa kinerja dosen PA berkategori rendah dan masalah akademik mahasiswa berada pada kategori sedang, , sehingga dapat disimpulkan bahwa hubungan antara kinerja dosen PA dengan masalah akademik mahasiswa. Tingkat korelasi antara kinerja dosen PA dengan masalah akademik mahasiswa sangat rendah atau tidak terlalu signifikan bahkan bisa dikatakan hampir tidakberkorelasi sama sekali.

Keyword: Kinerja Dosen PA, Masalah Akademik

Copyright @ 2013 IICE - Multikarya Kons (Padang - Indonesia) dan IKI - Ikatan Konselor Indonesia - All Rights Reserved

Indonesian Institute for Counseling and Education (IICE) Multikarya Kons

\section{PENDAHULUAN}

Kesuksesan mahasiswa dalam proses studinya pada hakekatnya merupakan suatu prestasi yang sangat diharapkan oleh semua pihak, bukan hanya mahasiswa itu sendiri melainkan juga oleh orang tua, dosen, dan juga kampus atau perguruan tinggi tempat mahasiswa tersebut melaksanakan proses perkuliahan

Ukuran kesuksesan mahasiswa dalam perkuliahannya tidak bisa diukur dari nilai tinggi semata atau dinilai dari cepat tamat saja, akan tetapi ada beberapa unsur yang bisa membuat seorang mahasiswa dikatakan sukses dalam sebuah perkuliahan, yang biasa disebut dengan tiga jenis sukses yaitu akademik, persiapan karir, sosial kemasyarakatan. Tiga hal tersebut adalah tiga rangkaian yang bisa dijadikan indikator dalam menentukan apakah seseorang tersebut sudah dikatakan sukses atau belum dalam perkuliahannya. Salah satu dari ketiga jenis atau kriteria sukses tersebut belum tercapai oleh mahasiswa, maka mahasiswa tersebut belum bisa dikatakan sukes dalam studinya. Hal ini sesuai dengan apa yang dikemukakan Prayitno (2007:3), bahwa sepanjang masa studinya sampai menamatkan studi di perguruan tinggi seorang mahasiswa dituntut untuk mencapai tiga jenis sukses, yaitu:

(1) Sukses akademik maksudnya adalah didalam menjalani proses perkuliahan seorang mahasiswa juga dituntut untuk memiliki sikap mandiri, mandiri dalam proses belajar, mandiri dalam menguasai dan memperoleh berbagai aspek sesuai dengan tujuan dan sasaran dari lembaga tempat merekaeka menuntut 
ilmu, yang meliputi wawasan, pengetahuan, keterampilan, nilai dan sikap dalam membentuk kesatuan keahlian yang hendak dikuasai.

(2) Sukses persiapan karir yaitu mahasiswa sudah seharusnya telah menguasai dengan baik materi kajian bidang keahlian yang ditempuhnya, berarti telah memiliki modal dengan menempuh karir yang sebenarnya di lapangan nanti.

(3) Sukses sosial kemasyarakatan yaitu mahasiswa telah memiliki kemampuan untuk dapat hidup dan bersosialisasi dalam kehidupan sosial masyarakat

Upaya mencapai kesuksesan dalam perkuliahan kerap kali mengalami hambatan-hambatan. Hambatan yang muncul dalam proses studi mahasiswa sering disebut sebagai masalah-masalah belajar. Masalah merupakan sesuatu yang menghambat, merintangi atau mempengaruhi seseorang mencapai maksud dan tujuan tertentu Winkel (1985:47). Dengan demikian dapat dinyatakan bahwa masalah belajar mahasiswa dalam proses perkuliahannya adalah sesuatu yang meng6 hambat mahasiswa dalam mencapai kesuksesan studi selama proses perkuliahannya.

Kendala-kendala yang dihadapi oleh mahasiswa dalam melaksanakan proses perkuliahannya disebut sebagai masalah akademik. Kartono (1995:57) menyebutkan bahwa masalah akademik meliputi masalah mengatur jadwal belajar, masalah dalam mempelajari buku pelajaran, kebiasaan belajar, dan kurang minat yang tinggi terhadap profesi yang seesuai dengan pendidikan yang diikutinya. Munculnya masalah akademik tersebut akan mempengaruhi motivasi mahasiswa dalam upaya untuk mencapai prestasi akademik yang diharapkan.

Masalah-masalah akademik pada dasarnya dimiliki oleh semua mahasiswa, namun yang membedakan adalah tingkatannya dan bagaimana mahasiswa tersebut menyikapi dan menyelesaikannya. Dalam kondisi tertentu, mahasiswa membutuhkan orang lain dalam mengatasi permasalahan belajar yang dialaminya, baik teman ataupun dosen. Oleh karena hal tersebut, dalam sistem pendidikan di perguruan tinggi ada tugas yang diberikan kepada dosen untuk secara khusus membimbing mahasiswa yang disebut sebagai penasehat akademik (PA). Dosen penasehat akademik (PA) memiliki tugas khusus untuk membimbing dan membantu mahasiswa, hal itu sesuai dengan penjelasan dari A. Muri Yusuf (1996: 3) yaitu "Penasehat Akademik merupakan perpanjangan tangan institusi untuk membantu mahasiswa sehingga setiap mahasiswa dapat mengikuti perkuliahan dengan teratur, sistematis dan berkelanjutan, efektif dan efisien". Melalui penasehat akademik, mahasiswa dapat meminta bimbingan dan arahan dalam menghadapi setiap permasalahan yang dialaminya selama proses belajar diperkuliahan.

Peran dan fungsi penasehat akademik sangatlah besar dalam mendukung keberhasilan belajar dari mahasiswa. Soekamto (1995:123) menjelaskan bahwa peran dosen penasehat akademik adalah menfasilitasi mahasiswa dalam mencapai prestasi belajar dilakukan dengan melakukan proses bimbingan dan penasehatan terhadap hal-hal yang terkait dengan perkuliahan.

Permasalahan yang terkait dengan kinerja dosen PA 1) selama ini mahasiswa sangat sulit menemui PA karena kesibukannya, bahkan beberapa mahasiswa selama mengikuti perkuliahan belum sekalipun memperoleh bimbingan dari dosen PA-nya, 2) waktu yang disediakan oleh dosen PA untuk mahasiswa yang singkat, sehingga mahasiswa tidak dapat mengungkapkan masalah yang dialaminya, 3) sebagian penasehat akedemik yang telah diberikan tugas oleh lembaga atau perguruan tinggi kerap kali karena alasan sibuk tidak bisa memberikan bimbingan kepada mahasiswa, 4) dosesn penasehat akademik kurang respek terhadap permasalahan yang dialami oleh mahasiswa, 5) sikap dosen penasehat akademik sering emosional ketika menghadapi mahasiswa yang berkonsultasi, sehingga mahasiswa merasa takut dan enggan menghadap dosen PA, 6) dosen sangat jarang memberikan bimbingan tentang cara menulis skripsi dan menentukan masalah penelitian yang baik. Kondisi seperti tersebut tentunya bukan merupakan fungsi dari adanya penasehat akademik dalam sistem perkulihan

Berdasarkan permasalahan tersebut, maka rumusan masalah dalam penelitian ini adalah: 1) Bagaimanakah kinerja dosen penasehat akademik (PA) di jurusan TV dan FILM ISI Padanganjang?, 2) Bagaimanakah gambaran masalah-masalah akademik yang dialami oleh mahasiswa jurusan TV dan FILM ISI Padangpanjang dalam proses perkuliahannya?, 3) Bagaimanakah hubungan antara kinerja dosen Penasehat Akademik dengan masalah- masalah akademik yang dialami mahasiswa jurusan TV dan FILM ISI Padangpanjang dalam perkuliahannya?

Tujuan penelitian adalah: mendeskripsikan kinerja dosen penasehat akademik (PA) di jurusan TV dan FILM ISI Pandangpanjang, mendeskripsikan masalah - masalah akademik yang dialami oleh mahasiswa jurusan TV dan FILM ISI Padangpanjang dalam perkuliahannya, dan mengetahui hubungan antara Kinerja dosen 
Penasehat Akademik dengan masalah-masalah akademik yang dihadapi mahasiswa jurusan TV dan FILM ISI Padangpanjang.

\section{METODOLOGI}

Penelitian ini merupakan penelitian kuantitatif dengan pendekatan korelasional. Populasi dalam penelitian ini adalah seluruh mahasiswa jurusan TV dan FILM ISI Padangpanjang. Untuk menentukan jumlah sampel penelitian teknik Simple Random Sampling, dan diperoleh jumlah sampel sebanyak 100 mahasiswa. Teknik pengumpulan data penelitian menggunakan skala likert. Data penelitian yang telah terkumpul akan dianalisis dengan teknik deskriptif, dan juga analisis korelasional.

\section{HASIL DAN PEMBAHASAN}

Sesuai dengan tujuan penelitian, maka hasil penelitian akan disajikan menjadi sub bagian-sub bagian sehingga akan mudah untuk memahami hasil penelitian yang telah diperoleh. Hasil penelitian secara rinci akan disajikan sebagai berikut:

a. Deskripsi Kinerja Dosen Penasehat Akademik (PA) di Jurusan TV dan FILM ISI Pandangpanjang

Indikator kinerja dosen PA dalam penelitian ini meliputi: a) Menyampaikan informasi kepada mahasiswa tentang berbagai peraturan akademik, b) Membantu mahasiswa dalam menyusun perencanaan studi, c) Membantu pembentukan sikap positif mahasiswa terhadap tugas yang harus dan perlu dipelajari, d) Membangkitkan motivasi belajar mahasiswa, e) Mendorong mahasiswa untuk selalu berupaya menemukan tujuan kuliah, dan f) Membantu mahasiswa dalam pembentukan sikap belajar. Rekapitulasi perhitungan data data kinerja dosen PA, adalah sebagai berikut:

Tabel 1.

\section{Rekapitulasi Perhitungan Data Kinerja Dosen PA}

\begin{tabular}{|c|l|c|c|c|c|c|c|}
\hline No & \multicolumn{1}{|c|}{$\begin{array}{c}\text { Indikator Kompetensi } \\
\text { Kinerja Dosen PA }\end{array}$} & \multicolumn{7}{|c|}{ Skor } & Kategori \\
\cline { 2 - 8 } & $\begin{array}{l}\text { Menyampaikan informasi } \\
\text { kepada mahasiswa tentang } \\
\text { peraturan akademik(9) }\end{array}$ & 9 & 42 & 45 & 2080 & 20,80 & Rendah \\
\hline 2 & $\begin{array}{l}\text { Membantu mahasiswa } \\
\text { menyusun perencanaan studi } \\
\text { (8) }\end{array}$ & 8 & 40 & 40 & 2246 & 22,46 & Sedang \\
\hline 3 & $\begin{array}{l}\text { Membantu pembentukan sikap } \\
\text { positif terhadap tugas (6) }\end{array}$ & 6 & 30 & 30 & 1544 & 15,44 & Rendah \\
\hline 4 & $\begin{array}{l}\text { Membangkitkan motivasi } \\
\text { belajar mahasiswa (6) }\end{array}$ & 6 & 23 & 30 & 1324 & 13,24 & Rendah \\
\hline 5 & $\begin{array}{l}\text { Mendorong mahasiswa untuk } \\
\text { selalu berupaya menemukan } \\
\text { tujuan kuliah (7) }\end{array}$ & 7 & 35 & 35 & 1774 & 17,74 & Rendah \\
\hline 6 & $\begin{array}{l}\text { Membantu mahasiswa dalam } \\
\text { pembentukan sikap belajar (8) }\end{array}$ & 8 & 40 & 40 & 1729 & 17,29 & $\begin{array}{l}\text { Sangat } \\
\text { rendah }\end{array}$ \\
\hline 7 & $\begin{array}{l}\text { Membantu mengentaskan } \\
\text { masalah mahasiswa (10) }\end{array}$ & 10 & 43 & 50 & 1785 & 17,85 & $\begin{array}{l}\text { Sangat } \\
\text { rendah }\end{array}$ \\
\hline
\end{tabular}


Untuk mengetahui penyebaran frekuensi pada setiap kategori, maka dilakukan analisi terhadap frekuensi dan juga besaran persentasenya. Berikut distribusi frekuensi pada setiap kategori:

Tabel 2.

Kategori Pencapaian Skor Kinerja Dosen Penasehat Akademik

\begin{tabular}{|l|l|l|l|}
\hline Klasifikasi & \multicolumn{1}{|c|}{ Kategori } & \multicolumn{1}{c|}{ f } & \multicolumn{1}{c|}{$\%$} \\
\hline 227 & Sangat tinggi & 1 & $1 \%$ \\
\hline $184-226$ & Tinggi & 10 & $10 \%$ \\
\hline $141-183$ & Sedang & 22 & $22 \%$ \\
\hline $98-140$ & Rendah & 37 & $37 \%$ \\
\hline$\leq 97$ & Sangat Rendah & 30 & $30 \%$ \\
\hline
\end{tabular}

Berdasarkan tabel di atas terlihat bahwa frekuensi terbesar berada pada kategori rendah. Dengan demikian disimpulkan bahwa kinerja dosen PA jurusan TV dan FILM ISI Padangpanjang berkategori rendah.

b. Deskripsi Masalah Akademik Mahasiswa

Rekapitulasi perhitungan data masalah akademik mahasiswa disajikan dalam tabel berikut:

Tabel 3.

Rekapitulasi Perhitungan Data Masalah Akademik Mahasiswa

\begin{tabular}{|c|c|c|c|c|c|c|c|}
\hline \multirow[b]{2}{*}{ No } & \multirow{2}{*}{$\begin{array}{l}\text { Indikator Masalah- } \\
\text { Masalah Akademik } \\
\text { Mahasiswa }\end{array}$} & \multicolumn{5}{|l|}{ Skor } & \multirow[t]{2}{*}{ Kategori } \\
\hline & & Min & $\operatorname{Max}$ & Ideal & Total & Rata-rata & \\
\hline 1 & $\begin{array}{l}\text { Masalah mengatur } \\
\text { jadwal belajar (7) }\end{array}$ & 7 & 32 & 35 & 2129 & 21,29 & Sedang \\
\hline 2 & $\begin{array}{l}\text { Masalah memilih } \\
\text { program sesuai } \\
\text { kemampuan }(5)\end{array}$ & 5 & 17 & 25 & 780 & 7,8 & Sangat Rendah \\
\hline 3 & $\begin{array}{l}\text { Masalah menyusun } \\
\text { makalah atau skripsi (8) }\end{array}$ & 8 & 40 & 40 & 2314 & 23,14 & Sedang \\
\hline 4 & $\begin{array}{l}\text { Mempelajari buku } \\
\text { bahasa asing }\end{array}$ & 5 & 24 & 25 & 1565 & 15,65 & Rendah \\
\hline 5 & $\begin{array}{l}\text { Masalah kurang } \\
\text { motivasi dalam belajar } \\
\text { (9) }\end{array}$ & 9 & 37 & 45 & 2580 & 25,80 & Sedang \\
\hline 6 & $\begin{array}{l}\text { Kebiasaan belajar } \\
\text { salah(5) }\end{array}$ & 5 & 23 & 25 & 1278 & 12,78 & Sedang \\
\hline 7 & $\begin{array}{l}\text { Rendah rasa } \\
\text { keingintahuan( 5) }\end{array}$ & 5 & 25 & 25 & 1222 & 12,22 & Rendah. \\
\hline
\end{tabular}
berikut:

Selanjutnya untuk mengetahui distribusi frekuensi pada setiap kategori dapat dilihat pada tabel

Tabel 4.

Kategori Pencapaian Skor Masalah Akademik Mahasiswa

\begin{tabular}{|l|l|l|l|}
\hline Klasifikasi & \multicolumn{1}{|c|}{ Kategori } & \multicolumn{1}{|c|}{ F } & \multicolumn{1}{|c|}{$\%$} \\
\hline 227 & Sangat tinggi & 0 & $0 \%$ \\
\hline $184-226$ & Tinggi & 9 & $9 \%$ \\
\hline $141-183$ & Sedang & 56 & $56 \%$ \\
\hline $98-140$ & Rendah & 30 & $30 \%$ \\
\hline$\leq 97$ & Sangat Rendah & 5 & $5 \%$ \\
\hline
\end{tabular}


Berdasarkan tabel di atas, diketahui bahwa frekuensi terbesar terletak pada kategori sedang. Dengan demikian disimpulkan bahwa masalah akademik yang dialami mahasiswa jurusan TV dan Film ISI Padangpanjang berada pada kategori sedang.

\section{c. Hubungan Antara Kinerja Dosen PA dengan Masalah Akademik Mahasiswa}

Untuk melakukan uji hipotesis sebelumnya dilakukan uji prasyarat analisis yaitu uji normalitas dan uji homogenitas. Uji normalitas dilakukan dengan analisis Lilliefors, dengan kriteria uji:

- Jika nilai $\mathrm{L}_{\text {maksimum }}<\mathrm{L}_{\text {tabel }}$, maka $\mathrm{H}_{\mathrm{o}}$ diterima ; data dikatakan normal.

- Jika nilai $\mathrm{L}_{\text {maksimum }}>\mathrm{L}_{\text {tabel }}$ maka $\mathrm{H}_{\mathrm{o}}$ ditolak; data dikatakan tidak normal.

Hasil uji normalitas dapat dilihat pada tabel berikut ini:

\section{Tabel 5. Uji Normalitas Data}

\begin{tabular}{|l|c|c|}
\hline Variabel & $\mathrm{L}_{\text {maksimum }}$ & $\mathrm{L}_{\text {tabel }}$ \\
\hline $\begin{array}{l}\text { Kinerja Dosen PA } \\
\text { Masalah } \\
\text { Akademik }\end{array}$ & 0.070 & 0,886 \\
& 0.085 & 0,886 \\
\hline
\end{tabular}

Berdasarkan tabel di atas, terlihat bahwa nilai $\mathrm{L}_{\text {maksimum }}<\mathrm{L}_{\text {tabel }}$, dengan demikian data penelitian normal. Selain menguji normalitas data, dilakukan juga uji homogenitas data penelitian. Kriteria homogen diperoleh jika signifikansi $>$ dari $\alpha(0,05)$. Hasil perhitungan homogenitas disajikan dalam tabel berikut ini:

Tabel 6. Uji Homogenitas Data

\begin{tabular}{|l|r|r|}
\hline & & \multicolumn{1}{|c|}{$\begin{array}{c}\text { Masalah } \\
\text { Akademik } \\
\text { Kinerja } \\
\text { Dosen PA }\end{array}$} \\
\hline Chi-Square & 18.500 & 36.800 \\
Df & 74 & 59 \\
Asymp. Sig. & 1.000 & .990 \\
\hline
\end{tabular}

Dari perhitungan diperoleh signifikansi data kinerja dosen PA sebesar 1.000 dan terbukti lebih besar dari 0,05 untuk data masalah akademik mahasiswa sebesar 0,990 besar dari 0,05. Berdasarkan perhitungan tersebut menunjukkan bahwa data kinerja dosen PA dan data masalah akademik mahasiswa adalah homogeny.

Hipotesis penelitian adalah terdapat hubungan antara kinerja dosen PA dengan masalah-masalah akademik mahasiswa. Kriteria uji hipotesis adalah sebagai berikut:

- Jika $r_{\text {rxy }} \neq 0$, maka Ho diterima ; Terdapat hubungan antara antara kinerja dosen penasehat akademik (PA) dengan masalah akademik mahasiswa

- Jika $r_{r x y}=0$, maka Ho ditolak ; tidak terdapat hubungan antara antara kinerja dosen penasehat akademik (PA) dengan masalah akademik mahasiswa . 
Hasil uji hipotesis adalah sebagai berikut:

Tabel 7. Hasil Uji Korelasi

\begin{tabular}{|l|c|c|}
\hline Variabel & $\begin{array}{c}\text { Koefisien } \\
\text { Korelasi }\left(r_{\text {rxy }}\right)\end{array}$ & $\rho$ \\
\hline $\begin{array}{l}\text { Kinerja dosen PA - } \\
\text { Masalah Akademik } \\
\text { Mahasiswa }\end{array}$ & 0,001 & 0.993 \\
\hline
\end{tabular}

Dari hasil perhitungan diperoleh koefisien korelasi sebesar 0.001 artinya adalah terdapat korelasi yang sangat rendah sekali yaitu hanya 0.001 dan bahkan bisa dikatakan hampir tidak punya korelasi sama sekali artinya Ho diterima dan Ha ditolak, dengan demikian terdapat hubungan antara antara kinerja dosen penasehat akademik (PA) dengan masalah akademik mahasiswa dalam kategori yang sangat rendah.

\section{PEMBAHASAN}

Pembahasan hasil penelitian dilakukan berdasarkan rumusan masalah dan tujuan penelitian. Secara rinci pembahasan terhadap hasil penelitian akan diuraikan sebagai berikut:

\section{Masalah Akademik Mahasiswa}

Berdasarkan hasil penelitian diperoleh keterangan bahwa tingkat masalah akademik yang dialami oleh mahasiswa ISI Padangpanjang pada jurusan TV dan FILM berada pada kategori sedang. Munculnya masalah akademik pada mahasiswa sering kali disebabkan oleh ketidaktahuan mahasiswa terhadap sistem belajar diperguruan tinggi. Mahasiswa kurang mengerti bagaimana strategi belajar dan menentukan jumlah sks. Padahal sistem sks dibuat dengan tujuan untuk menghargai prestasi mahasiswa dalam bidang atau bidang-bidang pengalaman belajar dalam rangka memenuhi syarat-syarat program pendidikan yang dikutinya (Oemar Hamalik, 2003: 35).

Belajar diperguruan tinggi pada umumnya memakan waktu yang cukup lama, hal inilah yang sering mendatangkan dan menimbulkan rasa jenuh dan malas belajar, belum lagi ditambah adanya tuntutan kemandirian yang lebih selama perkuliahaan, sering menjadikan beban tersendiri bagi mahasiswa. Aspekaspek tersebut secara langsung akan memunculkan masalah-masalah akademik mahasiswa dalam proses perkulihannya.

\section{Kinerja dosen PA}

Hasil yaitu penelitian menunjukkan bahwa kinerja dosen penasehat akademik (PA) di ISI Padangpanjang pada jurusan FILM dan TV berada pada kategori rendah. Hasil penelitian ini dapat dimaknai bahwa secara rata-rata dosen penasehat akademik belum melaksanakan tugas yang diamanatkan oleh lembaga atau institusi tempat mereka bekerja secara maksimal. Sudiyono (2004:22) menjelaskan bahwa pendidikan tinggi merupakan kegiatan dalam upaya menghasilkan manusia terdidik, manusia yang menjadi anggota masyarakat yang memiliki kemampuan akademik dan atau professional yang dapat menerapkan dan mengembangkan ilmu pengetahuan dan teknologi untuk meningkatkan taraf hidup masyarakat dan memperkaya kebudayaan nasional. Mencapai harapan masyarakat terhadap hasil pendidikan diperguruan tinggi dibutuhkan proses yang baik. Oleh karena itu peran dosen PA untuk menciptakan dan membantu keberhasilan mahasiswa dalam perkuliahannya sangat besar

3. Hubungan Antara Kinerja Dosen PA dengan Masalah Akademik Mahasiswa

Hasil penelitian menunjukkan bahwa terdapat hubungan antara kinerja dosen PA dengan masalah akademik mahasiswa dalam perkuliahan. Besaranya hubungan antara dua variable diatas adalah 0,001 , hal ini menunjukkan bahwa tingkat hubungan ini sangat rendah dan tidak terlalu signifikan dan hampir bisa dikatakan tidak berkorelasi sama sekali.

Oemar Hamalik (2003:124) menjelaskan peran dosen penasehat akademik dalam mengatasi masalah mahasiswa, yaitu "dosen penasehat akademik berperan membantu mahasiswa mengatasi masalah dan kesulitan dalam studinya, dan berperan membantu memecahkan masalah mahasiswa". Merujuk pendapat tersebut, ketika kinerja dosen rendah, maka munculnya masalah dan tidak terentaskan masalah mahasiswa 
akan tinggi, namun hasil penelitian menghasilkan hal yang berbeda. Analisis terhadap perbedaan itu dapat ditinjau dari pendapat Paryati Sudarman (2004:119) bahwa munculnya masalah mahasiswa erat terkait dengan lingkungan pergaulan mahasiswa, keuangan, dan masalah cinta dan pergaulan bebas. Masalahmasalah tersebut pada dasarnya bukan masalah akademik, namun memiliki pengaruh besar terhadap munculnya masalah akademik, dan ketika mahasiswa dapat mengelola atau terhindar dari masalah tersebut, tidak akan mengalami masalah secara signifikan walaupun kinerja dosen penasehat akademik tidak optimal. Selain itu, menurut Evita E. Singgih (2006:14) faktor yang mempengaruhi keberhasilan mahasiswa dalam perkuliahannya adalah motivasi belajar, inteligensi, minat, dan kesediaan waktu untuk belajar. Pendapat tersebutpun menegaskan bahwa peran PA sebenarnya lebih kepada fasilitator agar mahasiswa dapat belajar dengan baik, dan bukan faktor utama yang mempengaruhi kesuksesan mahasiswa dan terhindarnya masalah dalam perkuliahan.

\section{SIMPULAN DAN SARAN}

Berdasarkan temuan penelitian dan pembahasan yang telah dilakukan, maka kesimpulan penelitian adalah sebagai berikut: kinerja dosen penasehat akademik (PA) ISI Padang Panjang jurusan Film dan TV berada pada kategori rendah. Masalah akademik yang dialami oleh mahasiswa ISI Padangpanjang jurusan Film dan TV berada pada kategori sedang, jadi terdapat hubungan antara kinerja dosen penasehat akademik dengan masalah akademik mahasiswa, hal tersebut dapat dijelaskan dengan melihat kategori setiap variabel penelitian, yaitu kinerja dosen penasehat akademik berada pada kategori rendah, namun masalah akademik berada pada kategori sedang. Idealnya adalah ketika kinerja dosen penasehat akademik rendah, maka masalah akademik mahasiswa adalah tinggi.

Dari pembahasan diatas ditarik kesimpulan bahwa dosen PA yang ada di jurusan TV dan Film ISI Padangpanjang belum memberikan kontribusi terhadap masalah akademik mahasiswa dan belum melaksanakan tugasnya sebagaimana yang telah diamanatkan kepadanya. Keberadaan dosen PA tidak memberikan pengaruh terhadap masalah akademik mahasiswa.

Menindaklanjuti temuan penelitian sekaligus agar penelitian ini dapat memberikan kontribusi terhadap peningkatan kualitas perkuliahan dan meningkatkan peran dosen PA, maka saran dapat dirumuskan sebagai berikut: dosen PA diharapkan lebih memberikan waktu kepada mahasiswa yang ingin berkonsultasi tentang masalah akademiknya, sehingga mahasiswa dapat mengentaskan semua masalah yang dialaminya, selain itu kepada ketua Jurusan TV dan FILM ISI Padangpanjang disarankan untuk memotivasi para dosen PA agar senantiasa menjalankan amanat yang diembankan kepada dosen PA, dan juga bagi ketua jurusan hendaknya dapat mengevaluasi kinerja dosen PA dan memberikan pembinaan secara berkelanjutan kepada dosen-dosen PA yang kurang menjalankan kinerjanya, untuk mahasiswa disarankan dapat berperan aktif untuk mencari solusi-solusi terkait dengan masalah yang dialaminya. Mahasiswa hendaknya tidak tergantung kepada dosen PA saja untuk mencari informasi tentang perkuliahan, namun dapat mengoptimalkan berbagai sumber yang ada untuk mencari informasi yang berguna dalam menunjang proses perkuliahannya, dan bagi peneliti hendaknya dapat melakukan penelitian dengan variabel yang lebih kompleks dan menggunakan metode penelitian yang lain, sehingga hasil yang ditemukan lebih lengkap dan dapat berkontribusi dalam meningkatkan kualitas pendidikan diperguruan tinggi.

\section{DAFTAR RUJUKAN}

Abu Ahmadi dan Widodo. 1991. Psikologi Belajar. Jakarta: PT. Rineka Cipta

Abu Ahmadi dan Widodo. 1996. Peran Penasehat Akademis dalam Menunjang Proses Perkuliahan Mahasiswa di Perguruan Tiggi: Makalah . Padang: UNP

Crookston, B. B. 1994. A developmental view of academic advising as teaching. Journal. Vol 14. NACADA

Evita E. Singgih.2006. Sukses Belajar Di Perguruan Tinggi. Yogyakarta: Jalasutra

Kartini Kartono. 1995. Bimbingan Belajar di Perguruan Tinggi. Jakarta: Raja . Grafido Persada

Mudjiran. 1996. Teknik dan Strategi Pelaksanaan Kepenasehatan Akademik 
Oemar Hamalik. 2003. Manajemen Belajar Di Perguruan Tinggi. Bandung: Sinar Baru

Paryati Sudarman. 2004. Belajar Efektif Di Perguruan Tinggi.Bandung: Rekatama Media

Prayitno. 1990. Bahan Penataran Pembimbing Akademik Bagi Para dosen. Padang : LKIP Padang.

Sudiyono. 2008. Pemahaman Civitas Akademik FIP Terhadap VISI UNY: Insan, Cendekia, Mandiri dan Bernurani.Yogyakarta: UNY

Wibowo. 2001. Manajemen Kinerja. Jakarta: Bumi Aksara 